\title{
THE PLAINS ORB-WEAVER, Araneus gemmoides, IN SASKATCHEWAN
}

DON BUCKLE, 620 Albert Avenue, Saskatoon SK S7N 1 G7

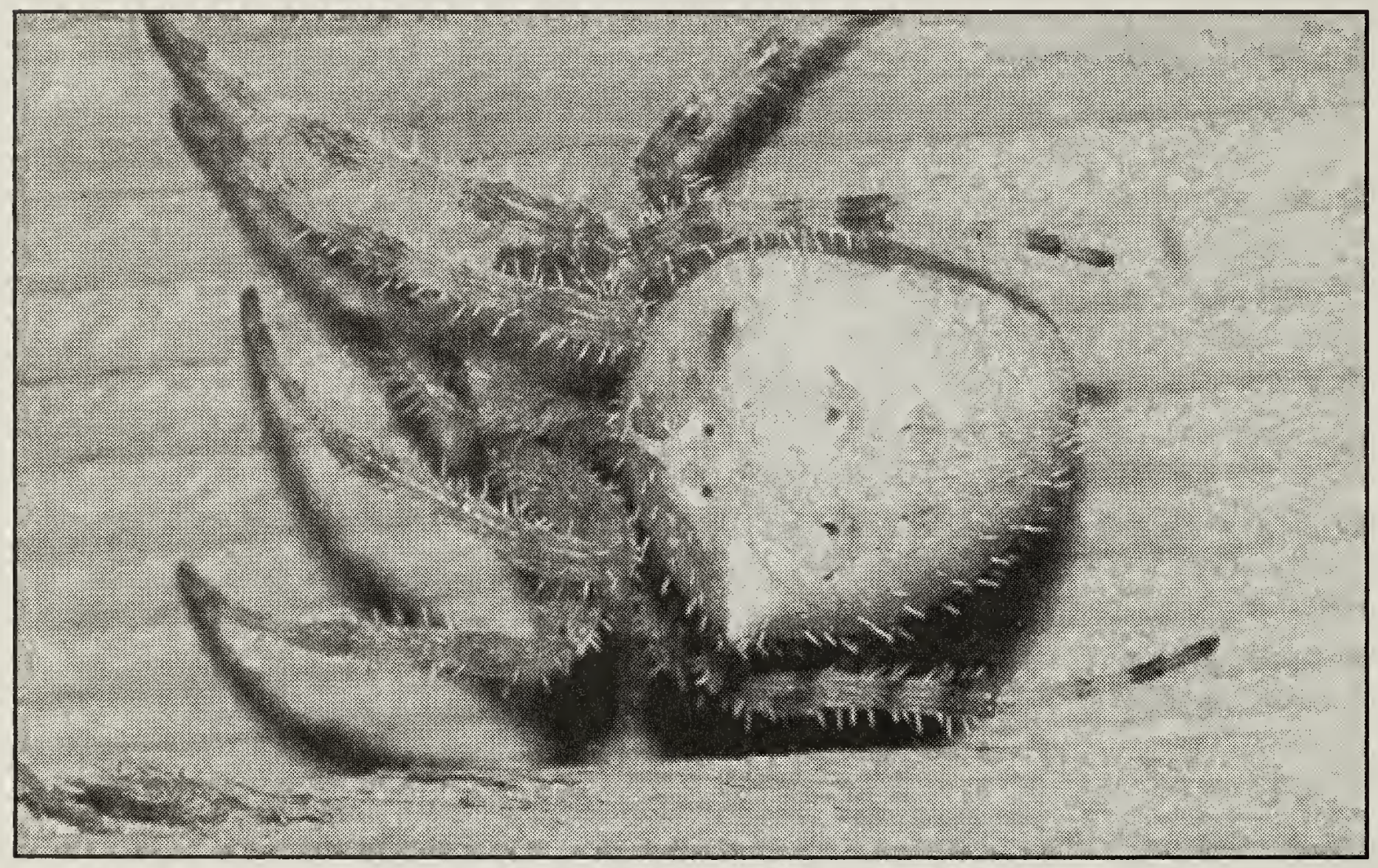

Plains Orb-weaver, female

George Tosh

With their large, humped abdomens which may be as much as $15 \mathrm{~mm}$ across, female Plains Orb-weavers are among our largest and most conspicuous spiders. They come in shades of brown, with indistinct markings on their abdomens and darker bands on their legs. Males are similar in appearance to the females but are much smaller and slimmer, being only 6 to $8 \mathrm{~mm}$ in length.

Plains Orb-weavers occur on the Great Plains and in the dry intermontane valleys of the west. They are common in the prairie region of Saskatchewan, and may be gradually extending their range northward. They were found as far north as Outlook in the mid-1960s, but were not seen in Saskatoon before 1983. Over the next few years they became abundant yard spiders.

Levi reported that Plains Orb-weavers were found associated with buildings in various parts of their range ${ }^{1}$. A few were collected in natural situations such as cave entrances, rocky ledges and chaparral. What the species' natural habitat is in Saskatchewan is an interesting but unanswered question. Here they are usually seen on or near man-made structures. They are common culvert residents in the southern part of the province and in Saskatoon are most frequently found on buildings, although some do build webs on yard trees and tall garden perennials. 


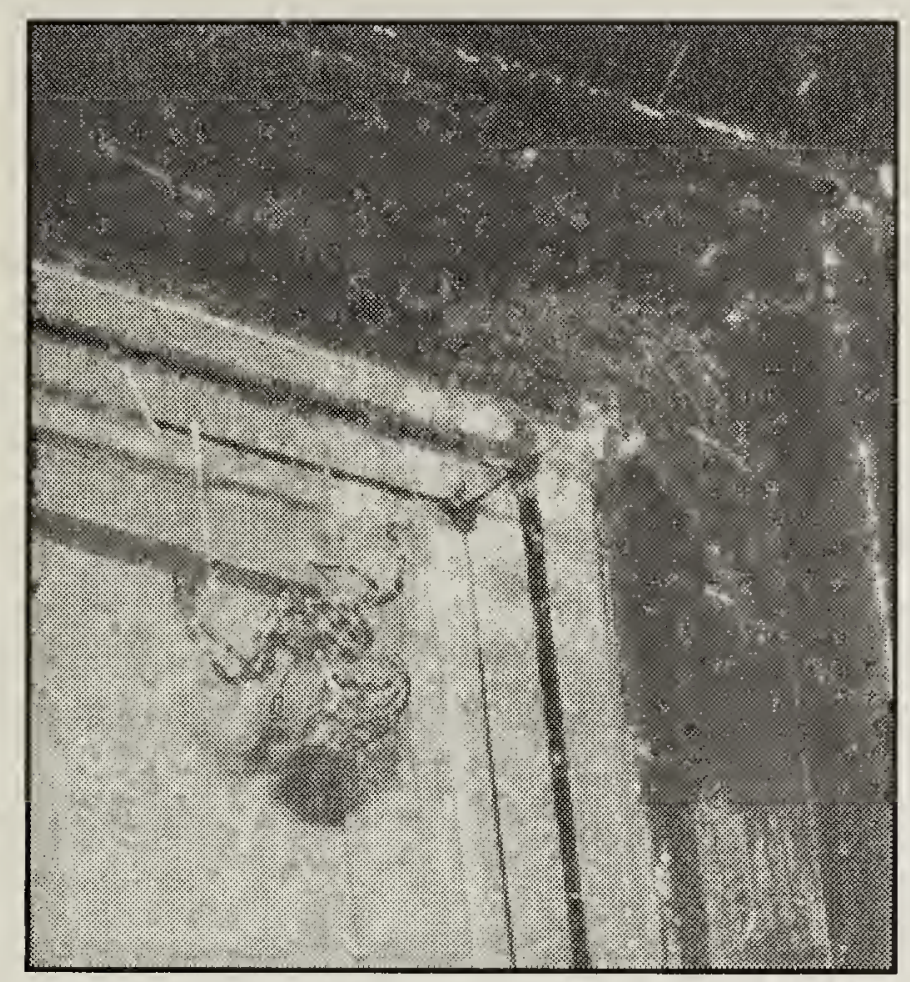

Female Plains Orb-weaver and her 'cell', the transparent crescent of webbing

George Tosh

The webs of mature females are over $30 \mathrm{~cm}$ in diameter. The spider builds a silk cell in a sheltered niche above the web and runs a stout thread down from her cell to the centre of the web. During the day she crouches in her cell with one leg on the thread to monitor vibrations from her web. When an insect is caught the spider feels its movements through the signal thread, rushes down ana captures it by swathing it in silk, then kills it with the venom of her bite. She will then usually snip it loose from the web and carry it back to her cell to eat. In late evening the spider refurbishes her web. She cuts away all but the major supporting threads then reconstructs the orb. During the night she hangs in the centre of her web and in early morning retreats once again to her cell.

Plains Orb-weavers mature in late July or early August. Females produce egg sacs, which may contain over a thousand eggs, in late September. The sacs are balls of fluffy orange silk 2 to $3 \mathrm{~cm}$ in diameter. The female remains with her egg sac for a few days, then wanders off and eventually dies. The eggs hatch the following spring and the youngsters are half grown by autumn. They mature in their second summer and the cycle is repeated.

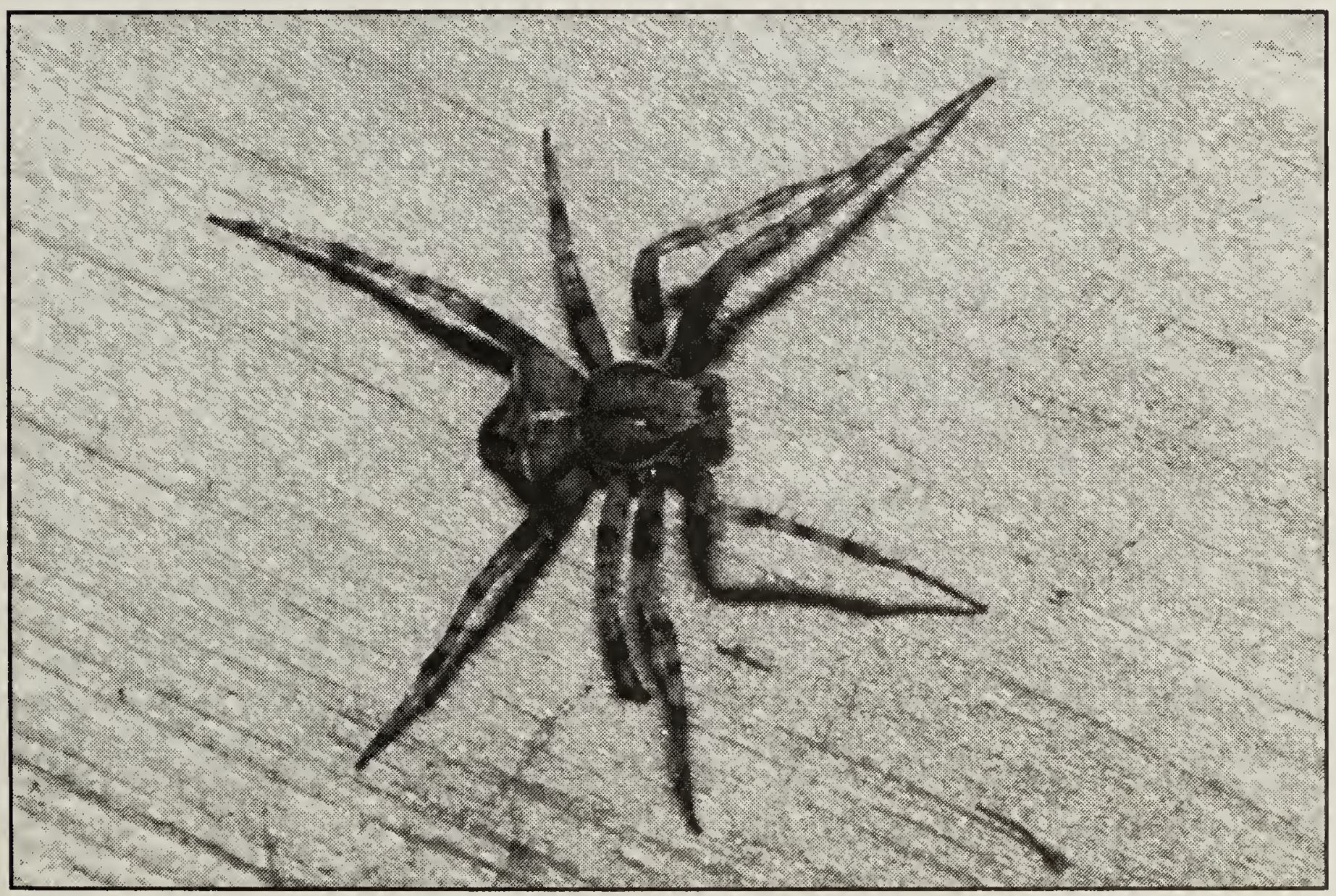


Because of their large size and association with man, Plains Orbweavers are an easy and convenient species to observe. In the autumn of 1998 I talked to Frank Hector who lives in a 6th floor apartment in Saskatoon. A female had built her web outside a window looking onto his balcony and he spent a considerable amount of time watching her spinning and feeding behaviour from his armchair. He saw her make her final moult to maturity. She rested for 20 minutes afterward, then took her moulted skin and chewed it into a little ball. This sort of behaviour may be common as it allows spiders to recover moisture and nutrients from the moulting fluid which has accumulated between their old and new skins. However, the only published reference I've been able to find is a note by Dondale ${ }^{2}$ who observed this behaviour in the crab spider Philodromus rufus. Unlike the Plains Orb-weavers, the crab spiders bit delicately through each leg tip of their moulted skins to sip the fluid.

1. Levi, H.W. 1971. The diadematus group of the orb-weaver genus Araneus north of Mexico. Bulletin of the Museum of Comparative Zoology, Vol. 141, \#4: 131-179.

2. Dondale, C.D. 1965. A spider's first meal after molting. The Canadian Entomologist 97: 446.

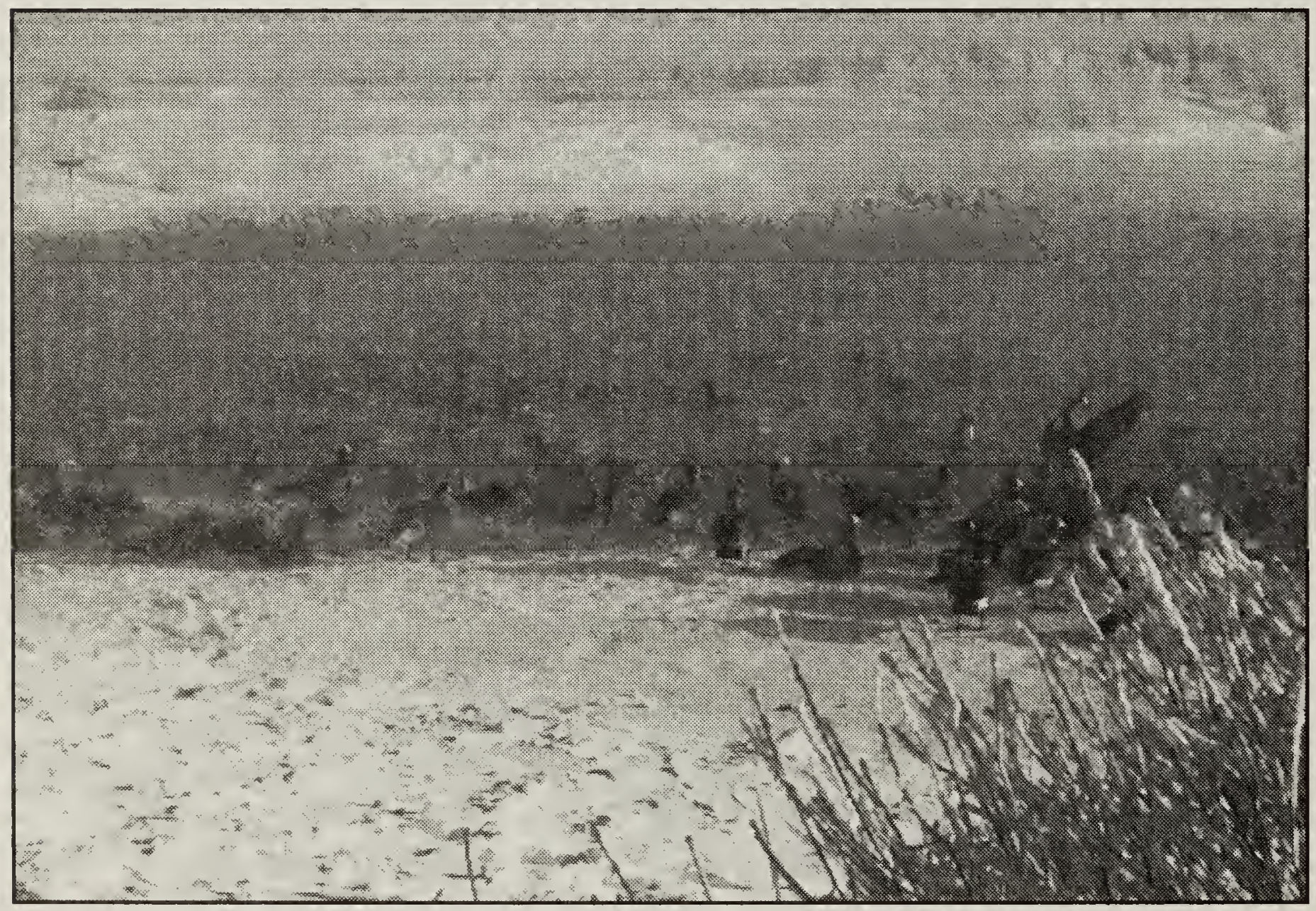

